\title{
Pemanfaatan Media Bimbingan dan Konseling di Sekolah Menengah Kejuruan Muhammadiyah se-Kota Yogyakarta
}

\author{
Hardi Prasetiawan, Said Alhadi \\ Program Studi Bimbingan dan Konseling, Fakultas Keguruan dan Ilmu Pendidikan, \\ Universitas Ahmad Dahlan, Jl. Pramuka No. 42, Yogyakarta, Daerah Istimewa Yogyakarta, Indonesia 55161 \\ E-mail: hardi.prasetiawan@bk.uad.ac.id
}

Artikel diterima: 25 Januari 2018; direvisi 30 April 2018; disetujui 30 April 2018

\begin{abstract}
The particular study aimed to know the utilization of media in guidance and counseling service provided by school counselor. Quantitative approach was used in the study. The research instrument was questionnaire with five alternative answers, such: very often; often; rare; sometime; and never. The result of the study showed the use of media in guidance and counseling service by school counselor ranging from visual media, electronic media; audio visual media; computer media
\end{abstract}

Keywords: media; services; guidance and counseling

\begin{abstract}
Abstrak: Studi ini bertujuan untuk mengetahui pemanfaatan media bimbingan dan konseling dalam layanan bimbingan dan konseling oleh guru bimbingan dan konseling. Metode yang digunakan menggunakan pendekatan kuantitatif. Instrumen yang digunakan berupa angket dengan lima alternatif jawaban yaitu: sangat sering; sering; jarang; kadang-kadang; dan tidak pernah. Hasil dari studi ini secara terperinci menunjukkan implementasi pemanfaatan media bimbingan dan konseling mulai dari media visual, media elektronik, media audio visual, dan media komputer dalam setiap layanan bimbingan dan konseling yang diberikan oleh guru bimbingan dan konseling.
\end{abstract}

Kata kunci: media; layanan; bimbingan dan konseling

Kemajuan teknologi merupakan sebuah tantangan yang tidak dapat dihindari dalam kehidupan saat ini (Susanto, 2012). Eksploitasi dari penggunaan perangkat komputer telah merambah ke berbagai bidang kehidupan. Era globalisasi yang berkembang pesat saat ini dan ditandai dengan majunya ilmu pengetahuan serta teknologi telah membawa perubahan di berbagai segi kehidupan manusia, mulai dari ekonomi, politik, sosial dan budaya serta pendidikan (Basri, 2010). Kehadiran teknologi juga dapat mempermudah kehidupan manusia dalam menjalani aktivitasnya (Johnni, 2009). Kemajuan teknologi memungkinkan manusia di belahan bumi barat dapat berkomunikasi dengan manusia lain yang berada di belahan bumi timur, ini merupakan hal yang tidak terbayangkan sebelumnya.

Dalam bidang bimbingan dan konseling, komunikasi terjadi lewat proses penyampaian pesan dari seseorang (sumber pesan) kepada seseorang atau sekelompok orang (penerima pesan), baik dari guru bimbingan dan konseling ke siswa, atau sebaliknya. Salah satu faktor yang memengaruhi komunikasi adalah penggunaan media dalam komunikasi tersebut (Hassell, 2013). Komunikasi dalam konteks bimbingan dan konseling adalah syarat mutlak, karena proses bimbingan dan konseling itu sendiri merupakan proses interaksi dan komunikasi oleh pihak yang terlibat dalam proses tersebut (Hariko, 2017). 
Guru bimbingan dan konseling wajib menguasai serta menerapkan standar kompetensi konselor yang telah ditentukan sebagai landasan dalam melaksanakan kegiatan layanan (Departemen Pendidikan Nasional, 2008). Peraturan Menteri Pendidikan Nasional Republik Indonesia tahun 2008, merumuskan standar kompetensi guru bimbingan dan konseling ke dalam empat kompetensi pendidik, yaitu: (1) kompetensi pedagogik; (2) kompetensi kepribadian; (3) kompetensi sosial; serta (4) kompetensi profesional. Guru bimbingan dan konseling harus menguasai dua komponen penting, yakni kompetensi akademik dan kompetensi profesional. Termasuk di dalamnya rincian kompetensi akademik guru bimbingan dan konseling untuk mengenal secara mendalam konseli yang hendak dilayani serta menguasai khasanah teoretik dan prosedural termasuk teknologi dalam bimbingan dan konseling.

Pelayanan bimbingan dan konseling di sekolah memberikan sumbangan besar pada keberhasilan siswa dalam belajar. Layanan bimbingan dan konseling yang diberikan pada siswa, dapat membantu siswa dalam mengatasi masalah yang dihadapi (Hanggara, 2016; Nurcahyani \& Fauzan, 2016; Saputra \& Prasetiawan, 2018). Pengoptimalan layanan bimbingan dan konseling dapat menggunakan media (Kettunen, Sampson Jr, \& Vuorinen, 2015), dimana media dimaksud adalah yang berfungsi untuk memaksimalkan perekaman permasalahan yang dihadapi siswa untuk dapat mengambil langkah penanganan yang tepat, menjaga kerahasiaan masalah yang dihadapi siswa agar tidak berpengaruh pada siswa secara psikologis, kemudahan komunikasi dengan jumlah siswa yang begitu banyak hanya ditangani oleh jumlah guru yang sangat terbatas.

Sebuah penelitian menunjukkan hasil sebesar $42,74 \%$ kinerja guru bimbingan dan konseling dari Sekolah Menengah Atas (SMA) Negeri tahun ajaran 2011-2012 telah mencapai kinerja yang baik (Hakim, 2011). Penjelasan hasil secara terperinci yaitu 57 dari 74 orang guru bimbingan dan konseling di kota Bandung termasuk pada kategori baik. Sebanyak sembilan orang lainnya masuk pada kategori cukup dan delapan orang pada kategori kurang. Faktor yang menyebabkan kinerja sebagian besar guru bimbingan dan konseling di Kabupaten Bandung belum optimal adalah kepribadian konselor, pengetahuan serta keterampilan memberikan layanan bimbingan.

Sejauh ini diduga belum semua guru bimbingan dan konseling yang berada di sekolah telah mencapai kualifikasi sesuai standar profesinya sebagai guru bimbingan dan konseling. Sebuah penelitian tentang penyelenggaraan layanan konseling terhadap guru bimbingan dan konseling, siswa, guru, dan kepala sekolah di Kabupaten Bandung menyebutkan bahwa umumnya kinerja guru bimbingan dan konseling belum memuaskan, $(64,28 \%)$ kinerja guru bimbingan dan konseling masuk pada kategori tidak memuaskan, sebagian kecil (35,71\%) masuk pada kategori memuaskan, dan tidak ada guru bimbingan dan konseling yang menunjukkan kinerja yang sangat memuaskan (Ilfiandra \& Ipah, 2006). Urutan aspek kinerja yang tidak memuaskan yang ditampilkan oleh guru bimbingan dan konseling menyangkut pengetahuan tentang keterampilan memberikan layanan bimbingan dan konseling (36,74\%), kepribadian guru bimbingan dan konseling (29,85\%), dan pengetahuan tentang layanan bimbingan dan konseling $(21,28 \%)$.

Melalui layanan bimbingan dan konseling, guru bimbingan dan konseling membantu peserta didik mencapai tugas perkembangannya dalam rangka proses kemandirian, hal tersebut akan menjadi lebih optimal jika didukung oleh pelaksana yang memiliki standar profesionalisme di bidangnya serta dukungan sistem manajemen yang berlaku serta pemanfaatan ilmu pengetahuan dan teknologi, sehingga kegiatan pendidikan menjadi lebih efektif.

Media layanan bimbingan dan konseling adalah segala sesuatu yang dapat digunakan untuk menyalurkan pesan atau informasi dari pembimbing kepada klien atau individu yang dapat merangsang pikiran, perasaan, perhatian, dan minat sehingga individu akan mengalami perubahan perilaku, sikap dan perbuatan ke arah yang lebih baik (Sari, 2012). Beberapa studi menunjukkan tentang penggunaan media dalam layanan konseling, seperti konseling kolaboratif berbasis information and communication technologies yang mana media information and communication technologies berhasil dikolaborasikan dengan model konseling yang telah ada untuk melaksanakan 
pelayanan bimbingan dan konseling (Hidayah \& Triyono, 2009), studi lain juga telah menunjukkan bahwa konsep aplikasi komputer untuk pelayanan bimbingan dan konseling memberikan hasil yang maksimal (Trianto, 2006).

Ciri-ciri umum yang terkandung dalam pengertian media adalah: (1) media memiliki pengertian fisik (hardware), yaitu suatu benda yang dapat dilihat, didengar atau diraba panca indera; (2) media memiliki pengertian non fisik (software), yaitu kandungan pesan yang terdapat dalam perangkat keras yang merupakan isi yang ingin disampaikan kepada siswa; (3) penekanan media terdapat pada visual dan audio; (4) media merupakan alat bantu pada proses belajar baik di dalam kelas maupun di luar kelas; (5) digunakan dalam rangka komunikasi dan interaksi pembimbing dan siswa dalam proses layanan; (6) dapat digunakan secara massal (misalnya: radio, televisi), kelompok besar dan kelompok kecil (misalnya: film, slide, video), atau perorangan (misalnya: komputer, modul, radio tape, video recorder) (Arsyad, 2016). Pemanfaatan media pada layanan bimbingan dan konseling dalam studi ini dapat berupa perangkat keras dan perangkat lunak yang digunakan oleh guru bimbingan dan konseling atau konselor sekolah ketika memberikan layanan, seperti di dalam layanan dasar, layanan peminatan dan perencanaan individual, layanan responsif, dan dukungan sistem.

Berdasarkan pada uraian di atas penggunaan media pada layanan bimbingan dan konseling dapat membantu efektifitas penyampaian layanan bimbingan dan konseling. Pemanfaatan media dalam layanan bimbingan dan konseling dapat memperjelas penyajian pesan atau informasi agar tidak verbalistis, mengatasi keterbatasan ruang, merubah perilaku dari yang tidak diinginkan menjadi sesuai yang diinginkan, dan menyamakan persepsi antara pembimbing dengan individu yang dibimbing. Tujuan dari penelitian ini adalah untuk mendeskripsikan pemanfaatan media bimbingan dan konseling dalam layanan bimbingan dan konseling di SMK Muhammadiyah seKota Yogyakarta.

\section{METODE}

Jenis penelitian ini adalah penelitian deskriptif dengan pendekatan kuantitatif, karena informasi data yang diperoleh disajikan dalam bentuk angka-angka dan dianalisis menggunakan analisis statistik (Arikunto, 2006). Penelitian bertujuan untuk mendeskripsikan pemanfaatan media pada layanan bimbingan dan konseling di SMK Muhammadiyah se-Kota Yogyakarta.

Populasi dalam penelitian ini adalah guru bimbingan dan konseling/konselor sekolah pada SMK Muhammadiyah se-Kota Yogyakarta yang subyeknya berjumlah sepuluh orang. Teknik sampling yang digunakan adalah purposive sampling. Instrumen yang digunakan dalam penelitian ini adalah angket tertutup berisi 25 pertanyaan dengan lima alternatif jawaban, dimana gradasi data angket pemanfaatan media bimbingan dan konseling disajikan pada tabel 1.

Validitas adalah suatu alat ukur yang mampu mengukur apa yang seharusnya diukur berdasarkan (Sugiyono, 2011). Maka dalam studi ini validitas yang digunakan pada instrumen pemanfaatan media bimbingan dan konseling dalam layanan bimbingan dan konseling berupa validitas konstruk yang telah melalui uji coba (try out) oleh uji ahli dan praktisi serta sehingga menghasilkan angket dengan uji kevalidan yang tinggi serta menggunakan reliabilitas alpha sebagai keakuratan/keajegan instrumennya.

Tabel 1 Gradasi Data Angket Pemanfaatan Media Bimbingan dan Konseling

\begin{tabular}{clc}
\hline No & \multicolumn{1}{c}{ Pernyataan } & Data \\
\hline 1 & Sangat Sering (SS) & 4 \\
2 & Sering (SR) & 3 \\
3 & Jarang (J) & 2 \\
4 & Kadang-Kadang (KK) & 1 \\
5 & Tidak Pernah (TP) & 0 \\
\hline
\end{tabular}




\section{HASIL}

Profil pemanfaatan media pada layanan bimbingan dan konseling di SMK Muhammadiyah seKota Yogyakarta dilihat dari hasil analisis data angket pemanfaatan media bimbingan dan konseling dalam layanan bimbingan konseling diuraiakan berdasarkan bantuan komputasi analisis sederhana menggunakan Microsoft Office Excel.

\section{Pemanfaatan Media pada Layanan Orientasi}

Teknik analasis data Pemanfaatan media pada layanan orientasi dianalisa melalui bantuan komputer dengan aplikasi Microsoft Office Excel disajikan pada tabel 2. Penjabaran hasil analisis tabulasi data angket Pemanfaatan Media Bimbingan Konseling dilihat dari Layanan Orientasi ditemukan bahwa dari sepuluh guru bimbingan dan konseling yang masing-masing diberikan angket dengan 25 pertanyaan maka didapatkan hasil dengan nilai tertinggi yaitu 93, yang dikategorikan sering, sedangkan terdapat nilai terendah yaitu 52 dengan kategori kadang-kadang maka dalam hal ini di dapatkan hasil nilai rata-ratanya adalah 73 yang masuk pada kategori jarang. Maka dalam hal ini, pemanfaatan media pada layanan orientasi dapat divisualisasikan melalui grafik pada gambar 1.

\section{Pemanfaatan Media pada Layanan Informasi}

Teknik analisis data pemanfaatan media pada layanan informasi dianalisa melalui bantuan komputer dengan aplikasi Microsoft Office Excel yang kemudian disajikan pada tabel 3. Penjabaran hasil analisis tabulasi data angket Pemanfaatan Media Bimbingan Konseling dilihat dari Layanan Informasi Tersebut ditemukan bahwa dari sepuluh guru bimbingan dan konseling yang masing-

Tabel 2 Tabulasi Pemanfaatan Media pada Layanan Orientasi

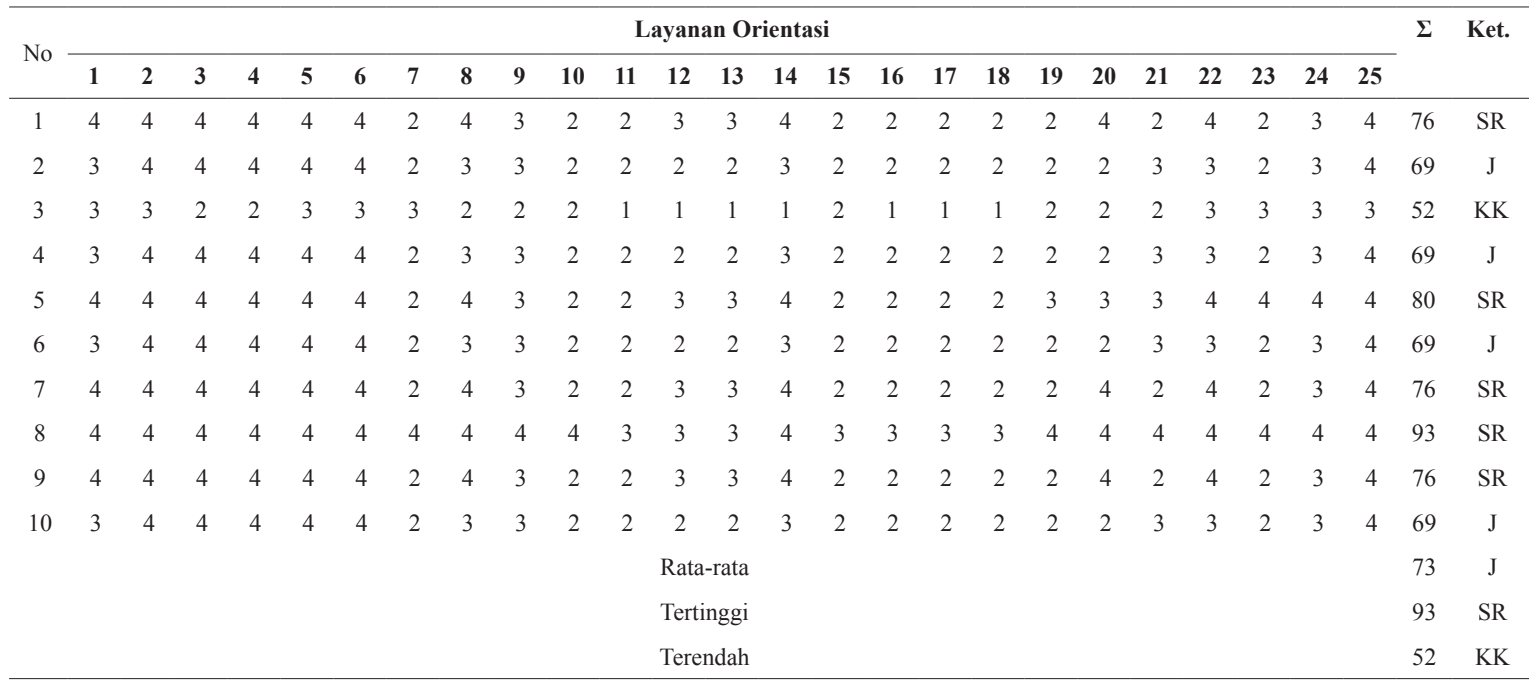

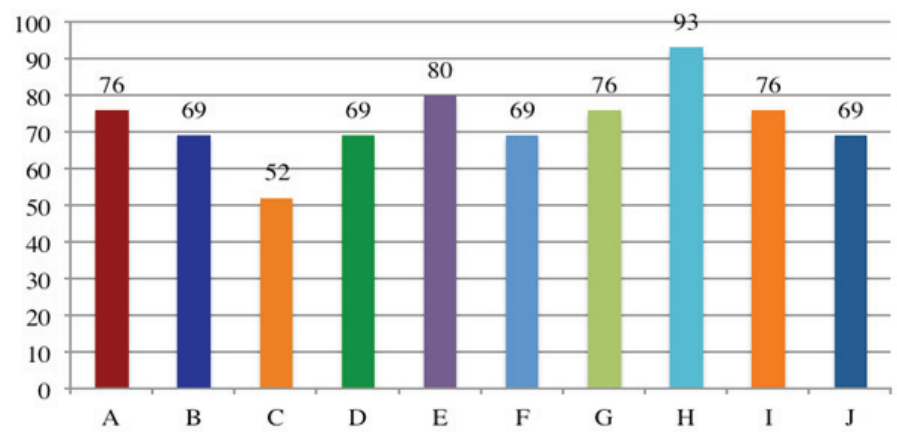

Gambar 1 Pemanfaatan Media pada Layanan Orientasi 
masing diberikan angket dengan 25 pertanyaan maka didapatkan hasil dengan nilai tertinggi yaitu 93 , yang dikategorikan sering, sedangkan terdapat nilai terendah yaitu 64 yang masuk kategori kadangkadang, maka dalam hal ini didapatkan hasil nilai rata-ratanya adalah 74 yang masuk kategori jarang. Maka dalam hal ini, pemanfaatan media pada layanan informasi dapat divisualisasikan melalui grafik pada gambar 2 .

\section{Pemanfaatan Media pada Layanan Penempatan Penyaluran}

Teknik analisis data pemanfaatan media pada layanan penempatan penyaluran dianalisa melalui bantuan komputer dengan aplikasi Microsoft Office Excel yang kemudian disajikan pada tabel 4. Penjabaran hasil analisis tabulasi data angket Pemanfaatan Media Bimbingan Konseling dilihat dari Layanan Penempatan Penyaluran ditemukan bahwa dari sepuluh guru bimbingan dan konseling yang masing-masing diberikan angket dengan 25 pertanyaan maka didapatkan hasil dengan nilai tertinggi yaitu 80, yang dikategorikan sering, sedangkan terdapat nilai terendah yaitu 52 yang masuk kategori kadang-kadang, maka dalam hal ini didapatkan hasil nilai rata-ratanya adalah 69 yang masuk kategori jarang. Maka dalam hal ini, pemanfaatan media pada layanan penempatan penyaluran dapat divisualisasikan melalui grafik seperti yang disajikan pada gambar 3 .

\section{Pemanfaatan Media pada Layanan Konseling Perorangan}

Teknik analisis data pemanfaatan media pada layanan konseling perorangan dianalisa melalui bantuan komputer dengan aplikasi Microsoft Office Excel yang kemudian disajikan pada tabel 5. Penjabaran hasil analisis tabulasi data angket Pemanfaatan Media pada Layanan Konseling

\section{Tabel 3 Tabulasi Pemanfaatan Media pada Layanan Informasi}

\begin{tabular}{|c|c|c|c|c|c|c|c|c|c|c|c|c|c|c|c|c|c|c|c|c|c|c|c|c|c|c|c|}
\hline \multirow{2}{*}{ No } & \multicolumn{25}{|c|}{ Layanan Informasi } & \multirow[t]{2}{*}{$\Sigma$} & \multirow[t]{2}{*}{ Ket. } \\
\hline & 1 & 2 & 3 & 4 & 5 & 6 & 7 & 8 & 9 & 10 & 11 & 12 & 13 & 14 & 15 & 16 & 17 & 18 & 19 & 20 & 21 & 22 & 23 & 24 & 25 & & \\
\hline 1 & 4 & 4 & 4 & 4 & 4 & 4 & 2 & 4 & 3 & 2 & 2 & 3 & 3 & 4 & 2 & 2 & 2 & 2 & 2 & 4 & 2 & 4 & 2 & 3 & 4 & 76 & SR \\
\hline 3 & 4 & 4 & 4 & 3 & 2 & 2 & 3 & 4 & 2 & 4 & 1 & 1 & 2 & 1 & 3 & 1 & 1 & 1 & 3 & 3 & 2 & 3 & 4 & 4 & 2 & 64 & $\mathrm{~J}$ \\
\hline 4 & 3 & 4 & 4 & 4 & 4 & 4 & 2 & 3 & 3 & 2 & 2 & 2 & 2 & 3 & 2 & 2 & 2 & 2 & 2 & 2 & 3 & 3 & 2 & 3 & 4 & 69 & $\mathrm{~J}$ \\
\hline 6 & 3 & 4 & 4 & 4 & 4 & 4 & 2 & 3 & 3 & 2 & 2 & 2 & 2 & 3 & 2 & 2 & 2 & 2 & 2 & 2 & 3 & 3 & 2 & 3 & 4 & 69 & $\mathrm{~J}$ \\
\hline 7 & 4 & 4 & 4 & 4 & 4 & 4 & 2 & 4 & 3 & 2 & 2 & 3 & 3 & 4 & 2 & 2 & 2 & 2 & 2 & 4 & 2 & 4 & 2 & 3 & 4 & 76 & SR \\
\hline 8 & 4 & 4 & 4 & 4 & 4 & 4 & 4 & 4 & 4 & 4 & 3 & 3 & 3 & 4 & 3 & 3 & 3 & 3 & 4 & 4 & 4 & 4 & 4 & 4 & 4 & 93 & SR \\
\hline 9 & 4 & 4 & 4 & 4 & 4 & 4 & 2 & 4 & 3 & 2 & 2 & 3 & 3 & 4 & 2 & 2 & 2 & 2 & 2 & 4 & 2 & 4 & 2 & 3 & 4 & 76 & SR \\
\hline \multicolumn{26}{|c|}{ Terendah } & 64 & KK \\
\hline
\end{tabular}

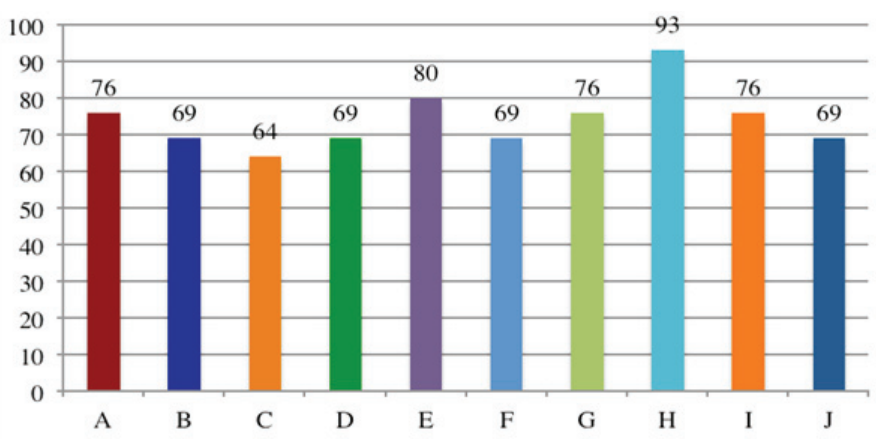

Gambar 2 Pemanfaatan Media pada Layanan Informasi 
Tabel 4 Tabulasi Pemanfaatan Media pada Layanan Penempatan Penyaluran

\begin{tabular}{|c|c|c|c|c|c|c|c|c|c|c|c|c|c|c|c|c|c|c|c|c|c|c|c|c|c|c|c|}
\hline No & \multicolumn{25}{|c|}{ Layanan Penempatan Penyaluran } & $\Sigma$ & Ket. \\
\hline 1 & 4 & 4 & 4 & 4 & 4 & 4 & 2 & 4 & 3 & 2 & 2 & 3 & 3 & 4 & 2 & 2 & 2 & 2 & 2 & 4 & 2 & 4 & 2 & 3 & 4 & 76 & SR \\
\hline 2 & 3 & 4 & 4 & 4 & 4 & 4 & 2 & 3 & 3 & 2 & 2 & 2 & 2 & 3 & 2 & 2 & 2 & 2 & 2 & 2 & 3 & 3 & 2 & 3 & 4 & 69 & $\mathrm{~J}$ \\
\hline 3 & 4 & 2 & 4 & 2 & 4 & 2 & 3 & 4 & 2 & 4 & 2 & 1 & 2 & 1 & 3 & 1 & 1 & 1 & 4 & 3 & 2 & 3 & 4 & 2 & 3 & 64 & $\mathrm{~J}$ \\
\hline 4 & 3 & 4 & 4 & 4 & 4 & 4 & 2 & 3 & 3 & 2 & 2 & 2 & 2 & 3 & 2 & 2 & 2 & 2 & 2 & 2 & 3 & 3 & 2 & 3 & 4 & 69 & $\mathrm{~J}$ \\
\hline 6 & 3 & 4 & 4 & 4 & 4 & 4 & 2 & 3 & 3 & 2 & 2 & 2 & 2 & 3 & 2 & 2 & 2 & 2 & 2 & 2 & 3 & 3 & 2 & 3 & 4 & 69 & $\mathrm{~J}$ \\
\hline 7 & 3 & 3 & 3 & 3 & 3 & 3 & 2 & 4 & 3 & 2 & 2 & 3 & 3 & 4 & 2 & 2 & 2 & 2 & 2 & 4 & 2 & 4 & 2 & 3 & 4 & 70 & $\mathrm{~J}$ \\
\hline 8 & 4 & 4 & 4 & 4 & 4 & 4 & 3 & 3 & 3 & 3 & 2 & 2 & 2 & 2 & 2 & 2 & 2 & 2 & 2 & 2 & 2 & 3 & 3 & 4 & 4 & 72 & $\mathrm{~J}$ \\
\hline 9 & 2 & 2 & 2 & 2 & 2 & 2 & 2 & 2 & 2 & 2 & 2 & 2 & 2 & 4 & 2 & 2 & 2 & 2 & 2 & 2 & 2 & 2 & 2 & 2 & 2 & 52 & KK \\
\hline \multicolumn{26}{|c|}{ Terendah } & 52 & KK \\
\hline
\end{tabular}

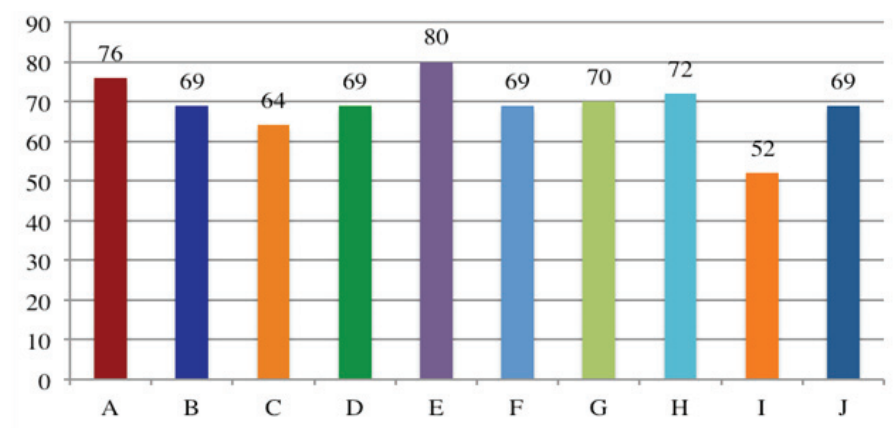

Gambar 3 Pemanfaatan Media pada Layanan Penempatan Penyaluran

perorangan ditemukan bahwa dari sepuluh guru bimbingan dan konseling yang masing-masing diberikan angket dengan 25 pertanyaan maka didapatkan hasil dengan nilai tertinggi yaitu 80 yang masuk pada kategori sering, sedangkan terdapat nilai terendah yaitu 33 yang masuk kategori kadang-kadang maka dalam hal ini didapatkan hasil nilai rata-ratanya adalah 64 yang masuk pada kategori jarang. Maka dalam hal ini, pemanfaatan media pada layanan konseling perorangan dapat divisualisasikan melalui grafik seperti yang disajikan pada gambar 4 .

\section{Pemanfaatan Media pada Layanan Konseling Kelompok}

Teknik analasis data pemanfaatan media pada layanan konseling kelompok dianalisa melalui bantuan komputer dengan aplikasi Microsoft Office Excel yang dapat kemudian disajikan pada tabel 6. Penjabaran hasil analisis tabulasi data angket Pemanfaatan Media pada Layanan Konseling Kelompok ditemukan bahwa dari sepuluh guru bimbingan dan konseling yang masing-masing diberikan angket dengan 25 pertanyaan maka didapatkan hasil dengan nilai tertinggi yaitu 93 yang masuk pada kategori sering, sedangkan terdapat nilai terendah yaitu 64 yang masuk pada kategori kadang-kadang maka dalam hal ini di dapatkan hasil nilai rata-ratanya adalah 78 yang masuk kategori jarang. Maka dalam hal ini, pemanfaatan media pada layanan konseling kelompok dapat divisualisasikan melalui grafik yang disajikan pada gambar 5 . 
Tabel 5 Tabulasi Pemanfaatan Media pada Layanan Konseling Perorangan

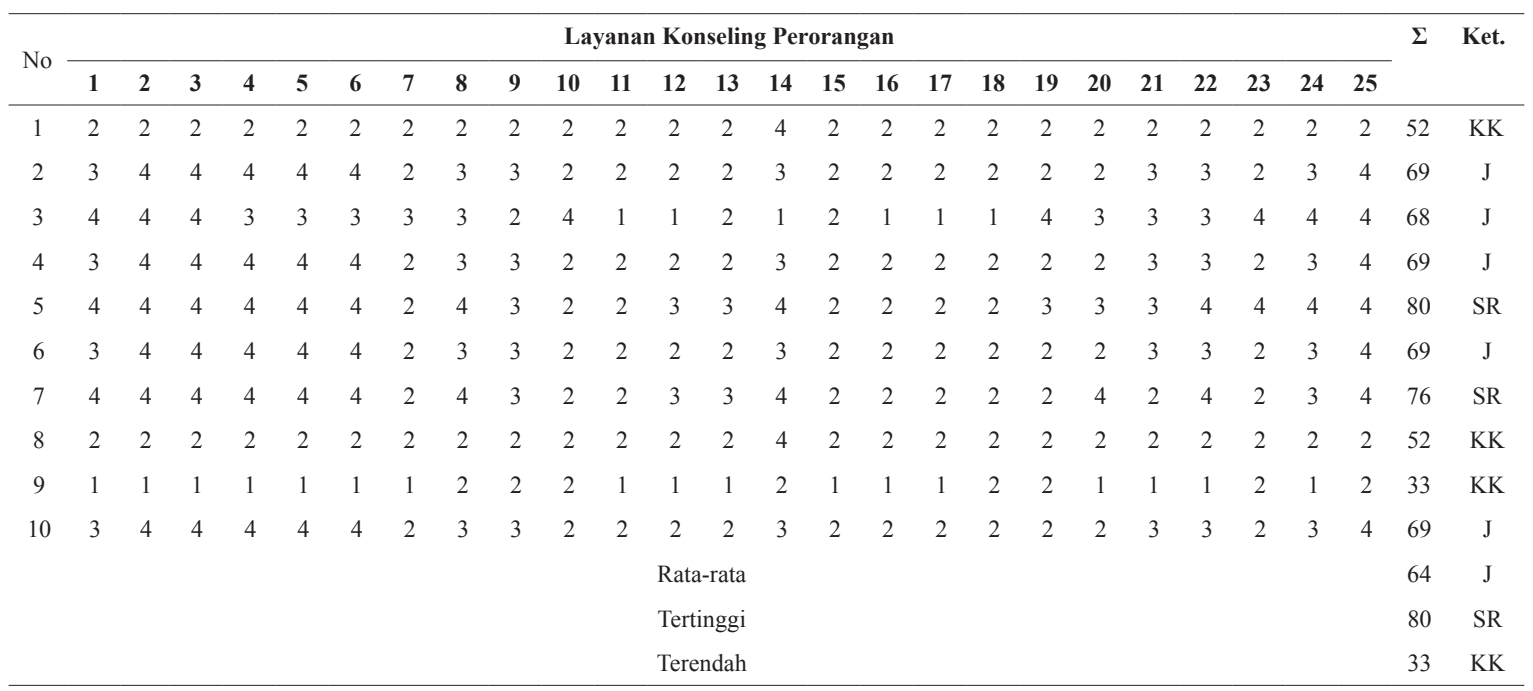

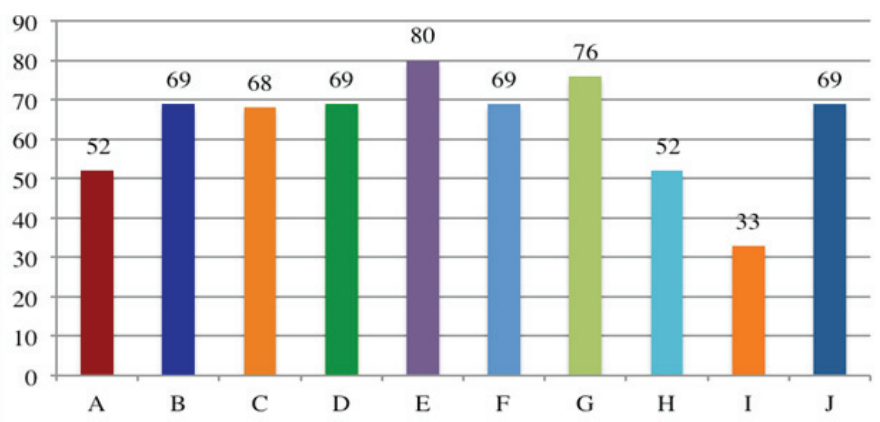

Gambar 4 Pemanfaatan Media pada Layanan Konseling Perorangan

Tabel 6 Tabulasi Pemanfaatan Media pada Layanan Konseling Kelompok

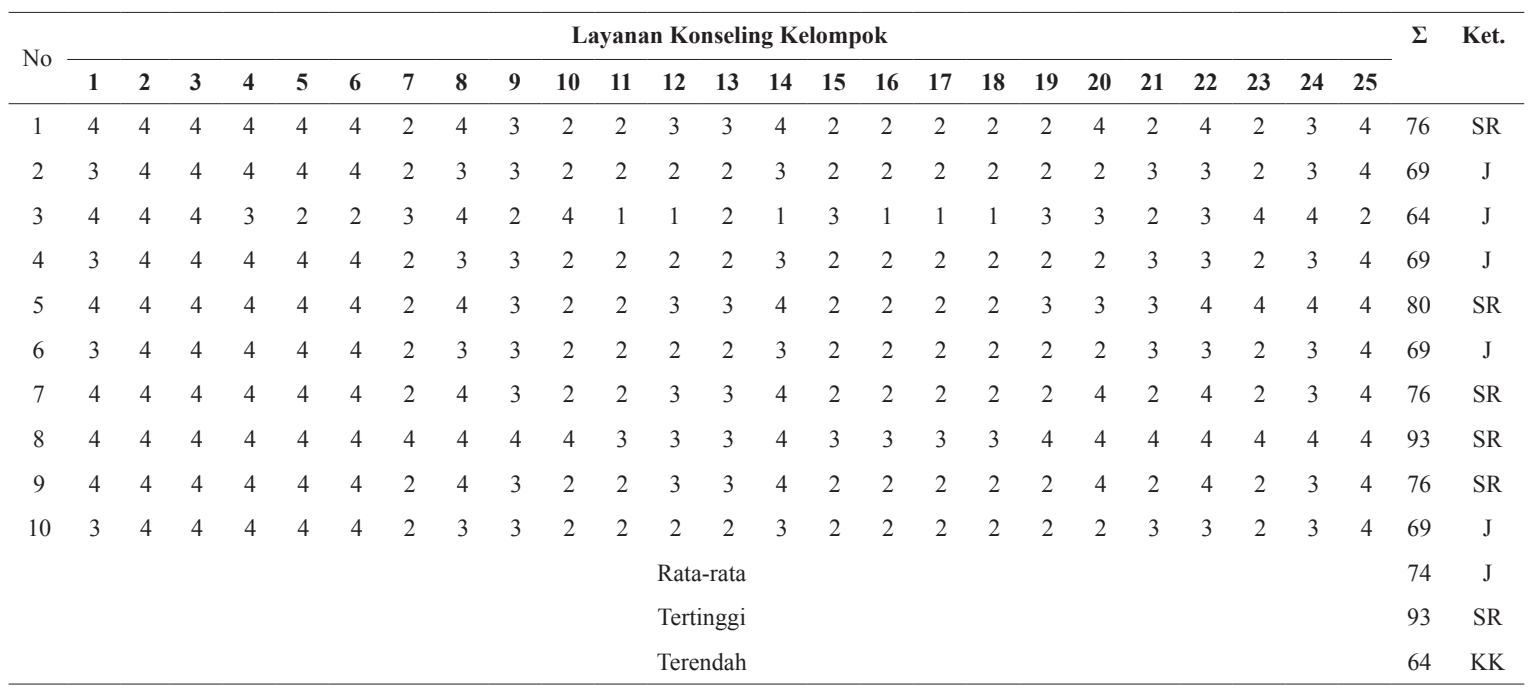




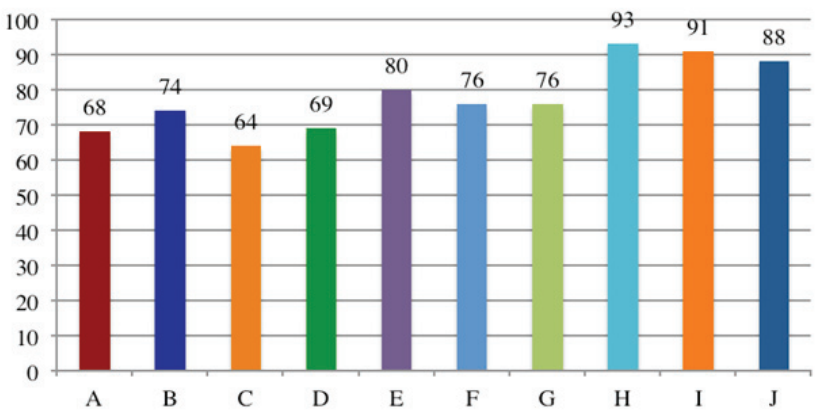

Gambar 5 Pemanfaatan Media pada Layanan Konseling Kelompok

\section{Pemanfaatan Media pada Layanan Bimbingan Kelompok}

Teknik analisis data pemanfaatan media pada layanan bimbingan kelompok dianalisa melalui bantuan komputer dengan aplikasi Microsoft Office Excel yang dapat dilihat pada tabel 7. Penjabaran hasil analisis tabulasi data angket Pemanfaatan Media pada Layanan Bimbingan Kelompok ditemukan bahwa dari sepuluh guru bimbingan dan konseling yang masing-masing diberikan angket dengan 25 pertanyaan maka didapatkan hasil dengan nilai tertinggi yaitu 96 yang masuk kategori sering, sedangkan terdapat nilai terendah yaitu 73 yang masuk kategori kadang-kadang, maka dalam hal ini di dapatkan hasil nilai rata-ratanya adalah 86 yang masuk kategori jarang. Maka dalam hal ini, pemanfaatan media pada layanan bimbingan kelompok dapat divisualisasikan melalui grafik yang disajikan pada gambar 6.

\section{Pemanfaatan Media pada Layanan Penguasaan Konten}

Teknik analasis data pemanfaatan media pada layanan penguasaan konten dianalisa melalui bantuan komputer dengan aplikasi Microsoft Office Excel yang disajikan pada tabel 8. Penjabaran hasil analisis tabulasi data angket Pemanfaatan Media pada Layanan Penguasaan Konten ditemukan bahwa dari sepuluh guru bimbingan dan konseling yang masing-masing diberikan angket dengan 25 pertanyaan maka didapatkan hasil dengan nilai tertinggi yaitu 71 yang masuk pada kategori sering, sedangkan terdapat nilai terendah yaitu 43 yang masuk kategori kadang-kadang, maka dalam hal ini di dapatkan hasil nilai rata-ratanya adalah 61 yang masuk kategori jarang. Maka dalam hal ini, pemanfaatan media pada layanan bimbingan kelompok dapat divisualisasikan melalui grafik yang disajikan pada gambar 7 .

Tabel 7 Tabulasi Pemanfaatan Media pada Layanan Bimbingan Kelompok

\begin{tabular}{|c|c|c|c|c|c|c|c|c|c|c|c|c|c|c|c|c|c|c|c|c|c|c|c|c|c|c|c|}
\hline \multirow{2}{*}{ No } & \multicolumn{25}{|c|}{ Layanan Bimbingan Kelompok } & \multirow[t]{2}{*}{$\Sigma$} & \multirow[t]{2}{*}{ Ket. } \\
\hline & 1 & 2 & 3 & 4 & 5 & 6 & 7 & 8 & 9 & 10 & 11 & 12 & 13 & 14 & 15 & 16 & 17 & 18 & 19 & 20 & 21 & 22 & 23 & 24 & 25 & & \\
\hline 1 & 4 & 4 & 4 & 4 & 4 & 4 & 4 & 4 & 4 & 4 & 4 & 4 & 4 & 4 & 4 & 2 & 2 & 2 & 4 & 4 & 4 & 4 & 4 & 4 & 4 & 94 & SL \\
\hline 3 & 3 & 3 & 3 & 4 & 3 & 3 & 3 & 3 & 4 & 3 & 3 & 3 & 3 & 3 & 3 & 1 & 1 & 1 & 3 & 3 & 3 & 3 & 4 & 4 & 3 & 73 & SR \\
\hline 4 & 4 & 4 & 4 & 4 & 4 & 4 & 4 & 4 & 4 & 4 & 4 & 4 & 4 & 4 & 4 & 3 & 1 & 3 & 4 & 4 & 4 & 4 & 4 & 4 & 4 & 95 & SL \\
\hline 6 & 4 & 4 & 4 & 4 & 4 & 4 & 4 & 4 & 4 & 4 & 4 & 4 & 4 & 4 & 4 & 1 & 2 & 3 & 4 & 4 & 4 & 4 & 4 & 4 & 4 & 94 & SL \\
\hline 7 & 4 & 4 & 4 & 4 & 4 & 4 & 2 & 4 & 3 & 2 & 2 & 3 & 3 & 4 & 2 & 2 & 2 & 2 & 2 & 4 & 2 & 4 & 2 & 3 & 4 & 76 & SR \\
\hline 8 & 4 & 4 & 4 & 4 & 4 & 4 & 4 & 4 & 4 & 4 & 4 & 4 & 4 & 4 & 4 & 3 & 2 & 3 & 4 & 4 & 4 & 4 & 4 & 4 & 4 & 96 & S \\
\hline 9 & 4 & 4 & 4 & 4 & 4 & 4 & 2 & 4 & 3 & 2 & 2 & 3 & 3 & 4 & 2 & 2 & 2 & 2 & 2 & 4 & 2 & 4 & 2 & 3 & 4 & 76 & SR \\
\hline \multicolumn{26}{|c|}{ Terendah } & 73 & KK \\
\hline
\end{tabular}




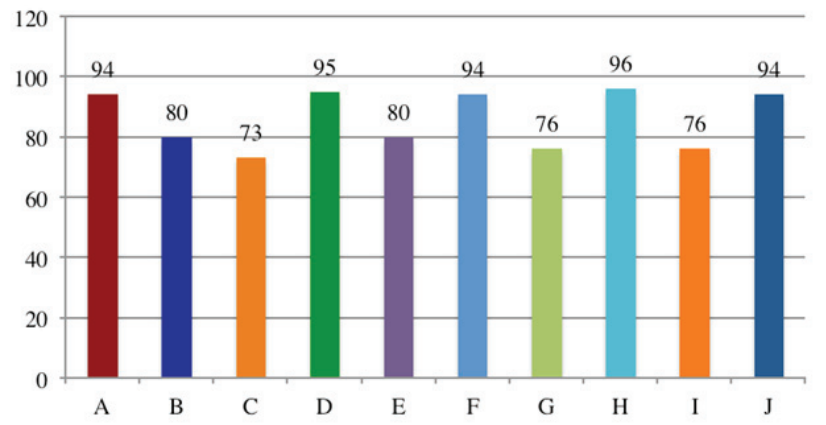

Gambar 6 Pemanfaatan Media pada Layanan Bimbingan Kelompok

Tabel 8 Tabulasi Pemanfaatan Media pada Layanan Penguasaan Konten

\begin{tabular}{|c|c|c|c|c|c|c|c|c|c|c|c|c|c|c|c|c|c|c|c|c|c|c|c|c|c|c|c|}
\hline No & \multicolumn{25}{|c|}{ Layanan Penguasaan Konten } & $\Sigma$ & Ket. \\
\hline 1 & 3 & 3 & 3 & 3 & 3 & 4 & 2 & 2 & 2 & 2 & 2 & 2 & 2 & 2 & 2 & 2 & 1 & 1 & 1 & 3 & 3 & 3 & 3 & 3 & 3 & 60 & $\mathrm{~J}$ \\
\hline 2 & 3 & 4 & 4 & 4 & 4 & 4 & 2 & 3 & 3 & 2 & 2 & 2 & 2 & 3 & 2 & 2 & 2 & 2 & 2 & 2 & 3 & 3 & 2 & 3 & 4 & 69 & $\mathrm{~J}$ \\
\hline 3 & 2 & 2 & 2 & 3 & 2 & 2 & 3 & 3 & 2 & 2 & 1 & 1 & 1 & 1 & 2 & 1 & 1 & 1 & 2 & 1 & 3 & 2 & 4 & 4 & 2 & 50 & KK \\
\hline 4 & 3 & 4 & 4 & 4 & 4 & 4 & 2 & 3 & 3 & 2 & 2 & 2 & 2 & 3 & 2 & 2 & 2 & 2 & 2 & 2 & 3 & 3 & 2 & 3 & 4 & 69 & $\mathrm{~J}$ \\
\hline 6 & 3 & 4 & 4 & 4 & 4 & 4 & 2 & 3 & 3 & 2 & 2 & 2 & 2 & 3 & 2 & 2 & 2 & 2 & 2 & 2 & 3 & 3 & 2 & 3 & 4 & 69 & $\mathrm{~J}$ \\
\hline 7 & 2 & 2 & 2 & 3 & 2 & 2 & 3 & 2 & 2 & 2 & 1 & 1 & 1 & 1 & 2 & 1 & 1 & 1 & 2 & 1 & 3 & 2 & 3 & 2 & 3 & 47 & KK \\
\hline 8 & 3 & 3 & 3 & 3 & 3 & 3 & 3 & 2 & 2 & 2 & 3 & 3 & 2 & 2 & 2 & 2 & 1 & 1 & 1 & 3 & 3 & 3 & 3 & 3 & 3 & 62 & $\mathrm{~J}$ \\
\hline 9 & 2 & 2 & 2 & 2 & 2 & 2 & 2 & 2 & 2 & 2 & 1 & 2 & 1 & 1 & 2 & 1 & 1 & 1 & 2 & 1 & 2 & 2 & 2 & 2 & 2 & 43 & KK \\
\hline \multicolumn{26}{|c|}{ Terendah } & 43 & KK \\
\hline
\end{tabular}

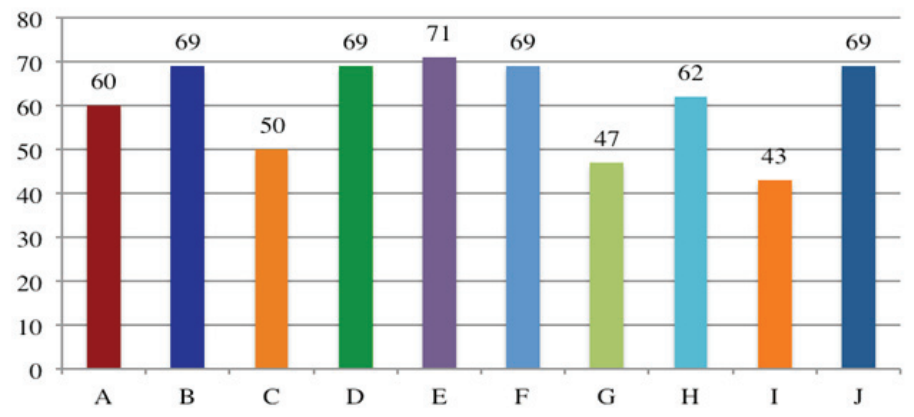

Gambar 7 Pemanfaatan Media pada Layanan Penguasaan Konten

\section{PEMBAHASAN}

Media bimbingan dan konseling merupakan suatu peralatan baik berupa perangkat lunak maupun perangkat keras yang berfungsi sebagai alat bantu dalam kegiatan layanan bimbingan dan konseling. Media bimbingan dan konseling juga dapat diartikan segala sesuatu yang digunakan menyalurkan pesan atau informasi dari pembimbing kepada siswa yang dapat merangsang pikiran, perasaan, perhatian, dan minat sehingga siswa akan mengalami perubahan perilaku, sikap dan perbuatan ke arah yang lebih baik. Media bimbingan dan konseling adalah segala sesuatu yang dapat digunakan untuk menyalurkan pesan bimbingan dan konseling yang dapat merangsang pikiran, perasaan, perhatian, dan kemauan siswa/konseli untuk memahami diri, mengambil keputusan, serta memecahkan masalah yang dihadapi (Nursalim, 2015). 
Pemanfaatan media dalam layanan bimbingan dan konseling telah banyak dilakukan, seperti penggunaan film (Auliyah \& Flurentin, 2016); modul (Atmaja, 2014); panduan (Irani, Handarini, \& Fauzan, 2018); dan musik (Raharjo, 2007). Pemanfaatan media oleh guru bimbingan dan konseling di SMK Muhammadiyah se-Kota Yogyakarta memiliki tingkat yang bervariatif dan hampir memiliki persamaan dalam setiap pelaksanaan layanannya yaitu terkategori jarang dalam setiap layanan bimbingan dan konseling yang diberikan.

Penggunaan media akan berdampak terhadap pelaksanaan layanan bimbingan dan konseling (Hazrati \& Hanim, 2016). Sebuah studi memberikan dukungan terhadap hasil studi pemanfaatan media bimbingan dan konseling dalam layanan bimbingan dan konseling yang sebagaimana peneliti lakukan dengan hasil manfaatnya bahwa media bimbingan dan konseling yaitu: (1) proses pemberian layanan akan lebih menarik perhatian siswa sehingga dapat menumbuhkan motivasi belajar; (2) materi layanan akan lebih jelas maknanya sehingga dapat lebih dipahami oleh siswa dan memungkinkannya menguasai dan mencapai tujuan layanan; (3) metode penyampaian materi atau pemberian layanan akan lebih bervariasi, tidak semata-mata komunikasi verbal melalui penuturan kata-kata oleh guru, sehingga siswa tidak bosan dan guru tidak kehabisan tenaga; (4) dalam proses pemberian layanan siswa dapat melakukan kegiatan mengamati, melakukan, mendemonstrasikan, memerankan, dll., tidak hanya mendengarkan (Arsyad, 2016).

Pemanfaatan media pada layanan orientasi, informasi, penempatan penyaluran, konseling perorangan, konseling kelompok, bimbingan kelompok, dan penguasaan konten oleh guru bimbingan dan konseling di SMK Muhammadiyah se-Kota Yogyakarta rata-rata memiliki kategori jarang karena hal ini berkaitan dengan kompetensi dan kualifikasi konselor dalam profesional serta dukungan dan kerjasama stakeholder di setiap sekolah. Selanjutnya, media yang jarang dimanfaatkan oleh guru bimbingan dan konseling dalam setiap layanan bimbingan dan konseling seperti jenis media visual (gambar, foto) dan media audio-visual (film, power point presentation). Adapun rincian seperti media berbasis cetak misalnya: buku panduan atau modul dan worksheet (lembar kerja). Media berbasis audio, misalnya: $m p 3$ musik relaksasi. Media berbasis audio-visual, misalnya: video; film; power point. Media berbasis komputer, misalnya: aplikasi macromedia flash.

Hal yang dapat muncul sebagai akibat dan konsekuensi dari jarangnya penggunaan media oleh guru bimbingan dan konseling di SMK Muhammadiyah se-Kota Yogyakarta adalah konselor kurang dapat mengeksplorasi materi yang diberikan sehingga kejelasan penyajian pesan atau informasi materi yang disampaikan membuat siswa menerima dan menangkap materi menjadi verbalistis. Kurangnya penggunaan media juga dapat membuat konselor kurang mampu mengatasi keterbatasan ruang dan mengelola waktunya, padahal salah satu kegunaan media adalah untuk mengatasi keterbasan ruang dan waktu (Fujii, Yokoyama, Yoshimi, \& Mizushima, 2017; Rejeesh \& Anupama, 2017) dan perubahan perilaku pada peserta didiknya yang diinginkan dapat menjadi kurang sesuai dengan yang diharapkan karena dengan media perubahan perilaku akan lebih efektif (Hazrati \& Hanim, 2016), serta kurang dalam menyamakan persepsi antara konselor dengan peserta didik yang dibimbingnya.

\section{SIMPULAN}

Dari sepuluh guru bimbingan dan konseling SMK Muhammadiyah se-Kota Yogyakarta menunjukkan bahwa pemanfaatan media visual sering dilakukan, pemanfaatan media elektronik kadang-kadang dilakukan, pemanfaatan media audio-visual termasuk dalam kategori jarang dilakukan, dan pemanfaatan media komputer sering dilakukan. Berkaca dari hasil tersebut, guru bimbingan dan konseling diharapkan lebih aktif lagi dalam memanfaatkan media dalam layanan bimbingan dan konseling agar mampu berkreasi dengan media yang ada, sehingga layanan yang diberikan lebih efektif dan siswa penerima layanan mendapatkan tambahan ilmu pengetahuan serta proses pemecahan masalahnya dapat terentaskan dengan baik di setiap layanan bimbingan dan konseling yang akan segera merubah cara belajarnya dari kemelut kebosanan. 


\section{DAFTAR RUJUKAN}

Arikunto, S. (2006). Prosedur Penelitian Suatu Pendekatan Praktek. Jakarta: PT Rineka Cipta. Jakarta: PT Rineka Cipta.

Arsyad, A. (2016). Media Pembelajaran. Bandung: Rajawali Press.

Atmaja, T. T. (2014). Upaya Meningkatkan Perencanaan Karir Siswa Melalui Bimbingan Karir dengan Penggunaan Media Modul. PSIKOPEDAGOGIA Jurnal Bimbingan dan Konseling, $3(2), 57-66$.

Auliyah, A., \& Flurentin, E. (2016). Efektifitas Penggunaan Media Film untuk Meningkatkan Empati Siswa Kelas VII SMP. Jurnal Kajian Bimbingan dan Konseling, 1(2), 19-26. https:// doi.org/10.17977/um001v1i12016p019

Basri, A. S. H. (2010). Peran Media dalam Layanan Bimbingan Konseling Islam di Sekolah. Jurnal Dakwah, 11(1), 23-41.

Departemen Pendidikan Nasional. Peraturan Menteri Pendidikan Nasional, Jakarta: Dirjen Pendidikan Dasar dan Menegah (2008).

Fujii, H., Yokoyama, T., Yoshimi, I., \& Mizushima, S. (2017). A Randomized Controlled Trial to Evaluate The Effects of Health Guidance with Video Call as Compared to Face-to-face Health Guidance. International Medical Journal, 24(2), 186-191.

Hakim, I. A. (2011). Program Supervisi untuk Meningkatkan Kinerja Guru Bimbingan dan Konseling di Sekolah (Studi Deskriptifke Arah Pengembangan Program Supervisi pada Beberapa Sekolah di Kota Bandung). Universitas Pendidikan Indonesia.

Hanggara, G. (2016). Keefektifan "Proses Guru” sebagai Teknik Bimbingan Kelompok dalam Meningkatkan Pengambilan Keputusan Karier Siswa SMK. Jurnal Kajian Bimbingan dan Konseling, 1(4), 148-157. https://doi.org/10.17977/um001v1i42016p148

Hariko, R. (2017). Landasan Filosofis Keterampilan Komunikasi Konseling. Jurnal Kajian Bimbingan dan Konseling, 2(2), 41-49. https://doi.org/http://dx.doi.org/10.17977/um001v2i22017p041

Hassell, M. (2013). Your Media Speak So Loud I Can't Hear a Word You're Saying: Impact of Media and Media Selection on Performance. ProQuest LLC.

Hazrati, R., \& Hanim, W. (2016). Pengaruh Media dalam Layanan Bimbingan Kelompok terhadap Pengaturan Diri Siswa Kelas XI di SMAN 56 Jakarta. Insight: Jurnal Bimbingan dan Konseling, 5(1), 94-99.

Hidayah, N., \& Triyono, T. (2009). Pengembangan Model Konseling Kolaboratif Berbasis ICT. In Kongres Nasional ABKIN. Surabaya.

Ilfiandra, A. M., \& Ipah, S. (2006). Peningkatan Mutu Tata Kelola Layanan Bimbingan dan Konseling Pada Sekolah Menengah Atas Provinsi Jawa Barat. Bandung: UPI.

Irani, L. C., Handarini, D. M., \& Fauzan, L. (2018). Pengembangan Panduan Pelatihan Keterampilan Mengelola Emosi sebagai Upaya Preventif Perilaku Bullying Siswa Sekolah Menengah Pertama. Jurnal Kajian Bimbingan dan Konseling, 3(1), 22-32. https://doi.org/10.17977/ um001v3i12018p022

Johnni, P. (2009). Stockholm - A City For Everyone How New Technology Can Make Every Day Life Easier for Elderly and People with Disabilities. In 16th ITS World Congress.

Kettunen, J., Sampson Jr, J. P., \& Vuorinen, R. (2015). Career Practitioners' Conceptions of Competency for Social Media in Career Services. British Journal of Guidance \& Counselling, 43(1), 43-56.

Nurcahyani, I., \& Fauzan, L. (2016). Efektivitas Teknik Relaksasi dalam Konseling Kelompok Behavioral untuk Menurunkan Stres Belajar Siswa SMA. Jurnal Kajian Bimbingan dan Konseling, 1(1), 1-6. https://doi.org/10.17977/um001v1i12016p001 
Nursalim, M. (2015). Pengembangan Profesi Bimbingan \& Konseling. Jakarta: Erlangga.

Raharjo, E. (2007). Musik sebagai Media Terapi. Harmonia: Journal of Arts Research and Education, $8(3)$.

Rejeesh, E., \& Anupama, M. (2017). Social Media and Data Mining Enabled Pre-counseling Session: A System to Perk Up Effectiveness of Counseling in Distance Education. In Proceedings of the International Conference on IoT in Social, Mobile, Analytics and Cloud, I-SMAC 2017 (hal. 153-156). https://doi.org/10.1109/I-SMAC.2017.8058328

Saputra, W. N. E., \& Prasetiawan, H. (2018). Meningkatkan Percaya Diri Siswa melalui Teknik Cognitive Defusion. Jurnal Kajian Bimbingan dan Konseling, 3(1), 14-21. https://doi. org/10.17977/um001v3i12018p014

Sari, A. K. (2012). Klasifikasi Media Bimbingan dan Konseling. Lampung: Fakultas Tarbiyah Jurusan Bimbingan Konseling Islam Institut Agama Islam Negeri Raden Intan.

Sugiyono. (2011). Metode Penelitian Kuantitatif, Kualitatif dan R \& D. Bandung: Alfabeta. https:// doi.org/10.1017/CBO9781107415324.004

Susanto, E. (2012). Penggunaan Media dalam Proses Bimbingan Kelompok untuk Mengembangkan Kreativitas (pada Siswa SMA Negeri 10 Bandar Lampung Tahun Ajaran 2007-2008). GUIDENA: Jurnal Ilmu Pendidikan, Psikologi, Bimbingan dan Konseling, 2(1), 13-27.

Trianto, A. (2006). Aplikasi Teknologi Komputer untuk Bimbingan dan Konseling. Paradigma, 1(1). 